\title{
Isolated Right Gastric Artery Injury Following A Blunt Trauma
}

\author{
Hiromitsu Nagata ${ }^{1}$, Naoki Yokoo ${ }^{1}$, Yasuhito Kitakado ${ }^{2}$, Takahiro Yoshida ${ }^{2}$ \\ Koji Kitamura $^{2}$, Tetsuya Shiota ${ }^{1}$, and Katsutaro Yasuda ${ }^{1}$
}

\begin{abstract}
A 54-year-old civil engineer received the weight of the tight quarter excavator for a moment at 11 am on June 1, 2002, while operating the one. The handlebar then struck him on the epigastrium. He was transported in an ambulance after about an hour after injury to our hospital, complaining of abdominal severe pain. He had epigastric pain with a golf ball-like swelling in the epigastric region. He had a remarkable tenderness with rebound pain on his upper abdomen without obvious external injury. Upper abdominal enhanced computed tomography visualized massive hematoma in bursa omentalis with extravasation of contrast media in lesser curvature of stomach, and moderate volume of a hemoperitoneum in liver border. He developed in hemorrhagic shock on examination at the emergency room. We suspected that he had intraabdominal hemorrhage possibly due to injury of visceral artery around the stomach, and an emergency laparotomy was performed for the purpose of hemostasis. At laparotomy, active bleeding from transected right gastric artery where it originated from the common hepatic artery with a large mass of hematoma in bursa omentalis was doubly ligated proximally and distally. The patient recovered uneventful and was discharged on the 14 th day after injury.
\end{abstract}

(JJAAM $2005 ; 16: 182-6$ )

Keywords: blunt abdominal trauma, right gastric artery injury, intraperitoneal hemorrhage, hemorrhagic shock Accepted for publication on December 6, $2004 \quad$ (04-075)

\section{Introduction}

Blunt abdominal trauma frequently results in injuries to the intra-abdominal organs. The mechanisms of these injuries can be explained by tangential tearing forces or crushing injury, and these injuries most often involve classically the liver, spleen, kidney, pancreas, gastrointestinal tract, genitourinary tract, and biliary tract. Blunt abdominal trauma rarely causes isolated vascular injuries. The frequency of isolated vascular injury currently accounts for approximately 3 per cent of all civilian vascular

\footnotetext{
${ }^{1}$ Department of Surgery, Takayama Red Cross Hospital

${ }^{2}$ Department of Emergency Medicine, Takayama Red Cross Hospital Academic affiliation:

Department of Surgery, Takayama Red Cross Hospital,

3-11 Tenman-cho, Takayama, Gihu 506-8550, Japan

Corresponding author:

Department of Gastroenterological Surgery, Kyoto University

Graduate School of Medicine

54 Kawara-cho, Shogoin, Sakyo-ku, Kyoto 606-8507, Japan
}

trauma ${ }^{1)}$. It is mostly caused by seatbelt injury secondary to motor vehicle collisions. We report a case of isolated right gastric artery injury from blunt trauma without other related injuries.

\section{Case Report}

A 54-year-old civil engineer momentarily bored with weight of a tight quarter excavator which overturned as he was loading it on a truck (Fig. 1a, b). The handlebar then struck him on the epigastrium (Fig. 1c). He was referred by an ambulance to our hospital about an hour after his injury, complaining of severe abdominal pain. His medical history had undergone a laparotomy due to a small intestinal perforation caused by a traffic accident at 44 years of age. On examination, his blood pressure and pulse rate were $130 / 80 \mathrm{mmHg}$ and $70 / \mathrm{min}$. He had severe epigastric pain with a golf ball-like swelling in the epigastric region. He had a marked tenderness with rebound pain on his upper abdomen without obvious external injury. Laboratory findings on arrival showed that the hemoglobin was $14.2 \mathrm{~g} / \mathrm{dl}$ and the remainders of his serum tests were within 

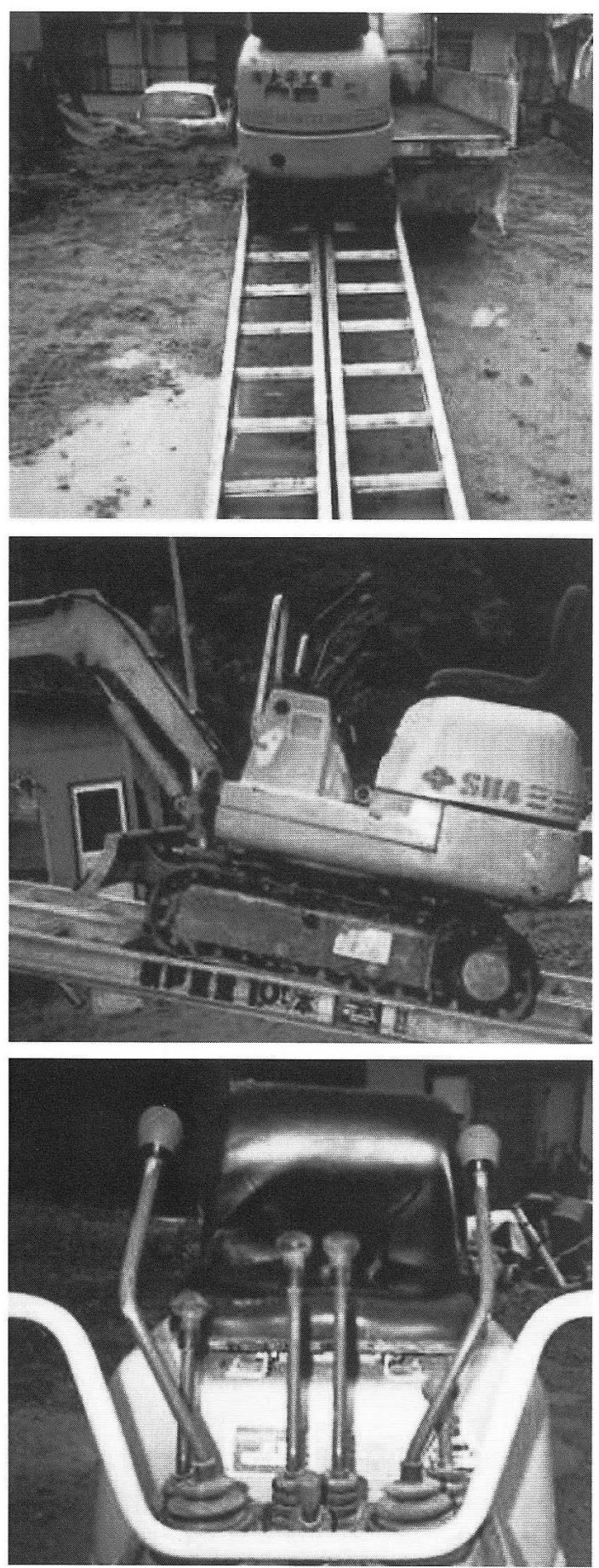

Fig. 1. The tight quarter excavator.

normal limits. X-rays of the abdomen were also normal. Upper abdominal enhanced computed tomography visualized of the fasciae laceration rectus abdominis muscle near by the epigastric region with disposition of some greater omentum out of the abdominal cavity to the sub-
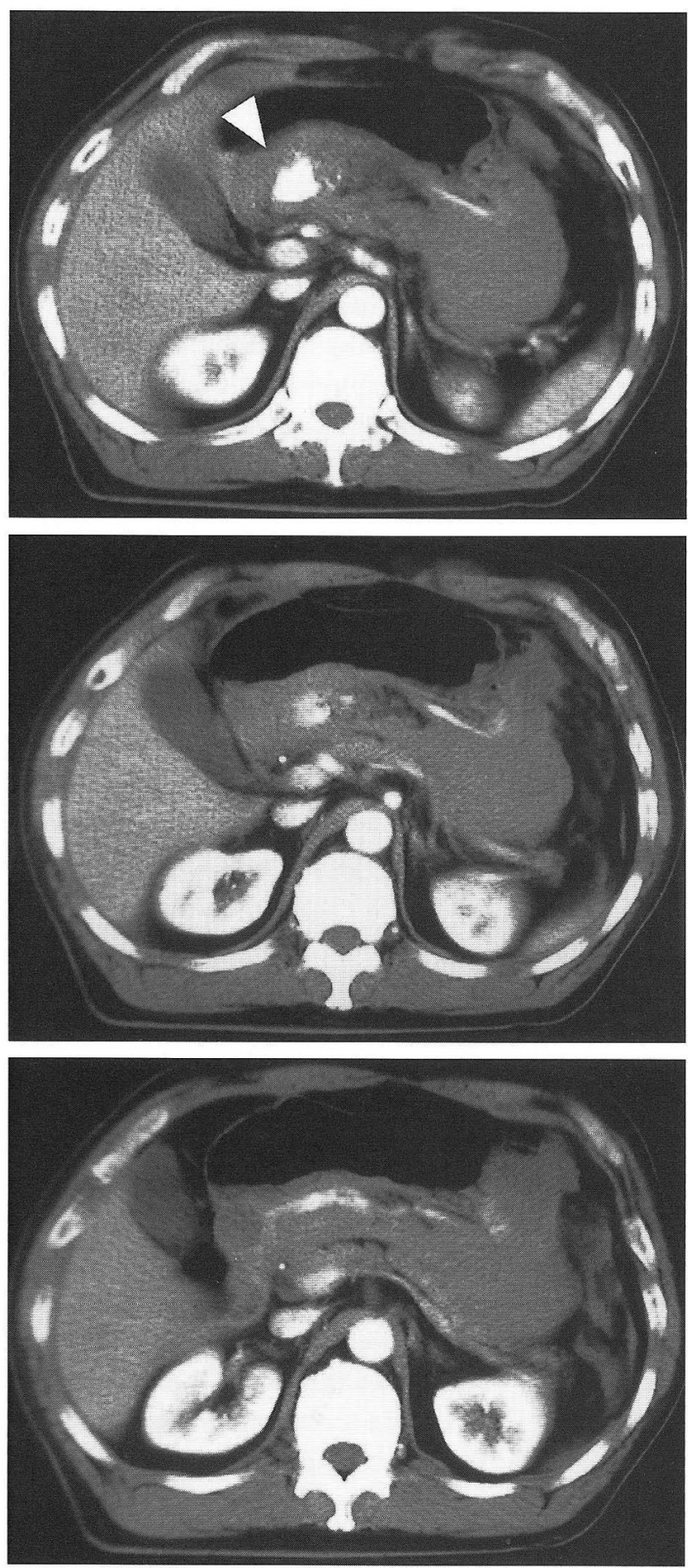

Fig. 2. Abdominal enhanced computed tomography on admission. The arrow demonstrates extravasation of contrast media along the lesser curvature of stomach.

cutis, massive hematoma in the bursa omentalis with extravasation of contrast media along the lesser curvature of the stomach, and moderate volume of hemoperitoneum in liver circumference (Fig. 2). The computed tomography showed no evidence of other injuries of abdominal aorta, 
portal vein and inferior vena cava. His blood pressure gradually dropped to below $90 \mathrm{mmHg}$ following his arrival at hospital, and he developed in hemorrhagic shock during the examination. His hemoglobin rapidly lowered to $9.7 \mathrm{~g} / \mathrm{dl}$ during blood examination. We suspected that he had intraabdominal hemorrhage as a result of arterial injuries around the stomach by the abdominal enhanced computed tomography. After about 2 hours from the injury, an emergency laparotomy was performed for the purpose of hemostasis and exploration of other abdominal visceral injuries. At laparotomy, an upper abdominal hernia of the greater omentum to the subcutis with diastasis recti about $4 \mathrm{~cm}$ in length and also the adhesion of greater omentum to the abdominal wall due to the previous operation were found. Active bleeding from the transected right gastric artery originated from the common hepatic artery with a large mass of hematoma in bursa omentalis was doubly ligated proximally and distally. The other abdominal organs were normal. A total of 9 units of packed red blood cells and 5 units of fresh-frozen plasma were administered. The patient had an uncomplicated recovery and was discharged on the 14th day after the injury.

\section{Discussion}

The most common cause for blunt abdominal trauma in industrialized countries is automobile accidents, and the mechanisms of abdominal trauma are impact against the steering wheel or an improperly placed lap-type seatbelt. Isolated major visceral arterial injuries caused by blunt trauma are rare. In particular, isolated right gastric artery injury caused by blunt trauma is particularly rare. Review of the Japanese literature revealed no previously reported cases of isolated right gastric artery injury following a blunt trauma. This extremely low incidence for major visceral vascular injuries have been accounted for prominently lethal injuries and died of exsanguinations before medical intervention. In review of the literature, injuries to the abdominal aorta and its visceral branches are potentially fatal due to exsanguination, with reported mortality rates in excess of 50 percent $^{2}$. Accordingly, immediate operative intervention is mandatory.

The pathophysiology of blunt abdominal vascular trauma consists of two mechanisms, which are compression and deceleration type. Compression involves avulsion of large arteries or visceral small branches with free hemorrhage into the abdominal cavity leading to shock, whereas deceleration results in intimal tear and secondary thrombosis of the arterial lumen ${ }^{3)}$. In our case, it is hy-
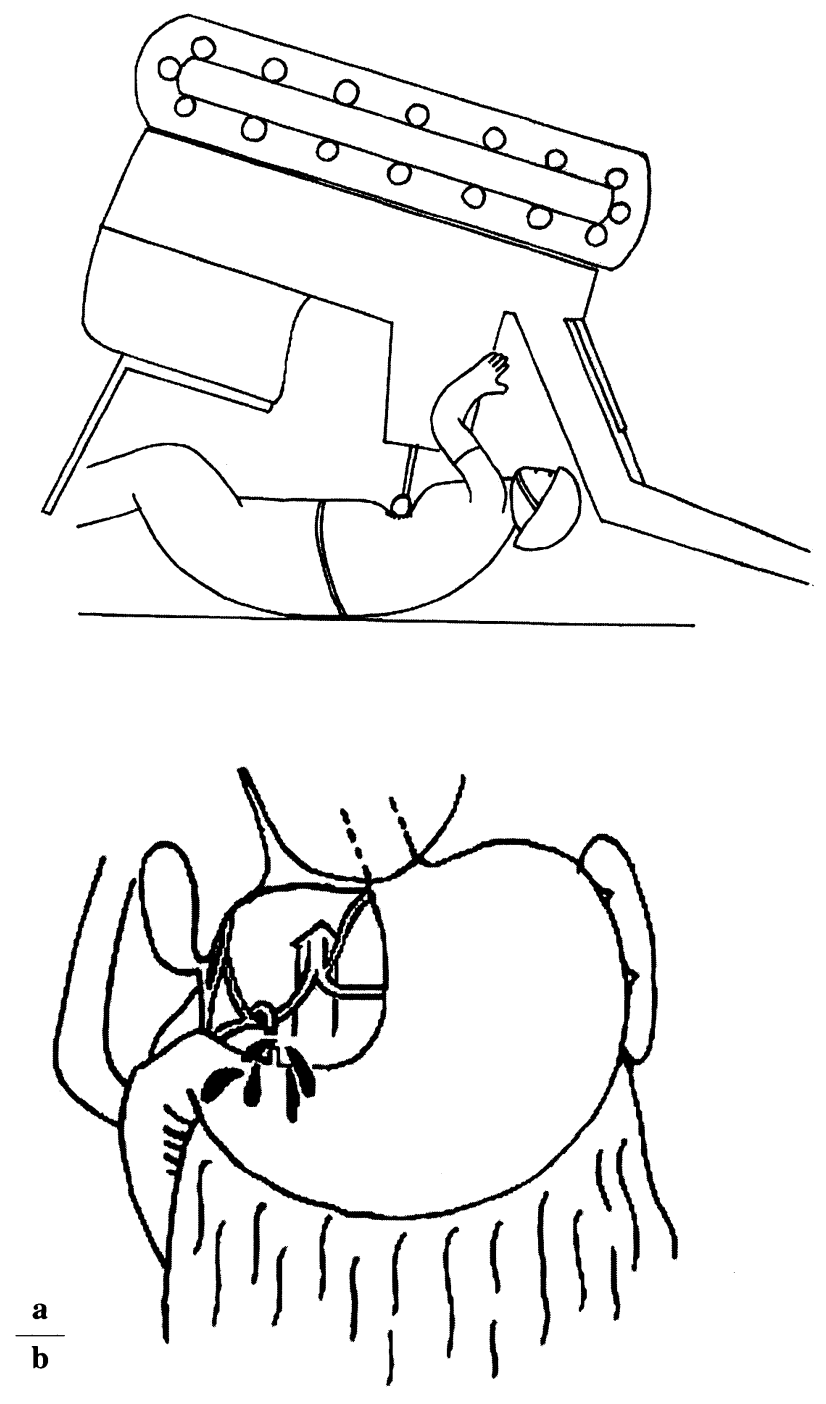

Fig. 3. Scheme of our case.

a: The mechanism of injury.

b: The right gastric artery was disrupted from the hepatic artery and actively exsanguinated.

pothesized that the impact of the handlebar resulted in a compression injury. Specifically, we thought that the injury observed in this patient was probably due to two factors; the sudden displacement of the stomach and duodenum by the handlebar's impact to the epigastrium, and avulsion of the omentum resulting from the adhesion of greater omentum to the abdominal wall due to the previous operation. In addition, there are some reports as to the importance of the amount of atheromatous disease present in the injured vessels. Early reports concluded that arteriosclerosis was not related to the injury, but more recent literature seems to imply that the loss of elasticity and compliance of the vessel plays a role in the genesis of ar- 
terial injury ${ }^{4)}$.

Other factors influencing the transfer of energy to the right gastric artery include the character of the trauma, the state of contraction of the abdominal wall, and the body build of the individual.

The diagnosis of abdominal vascular injuries is predicated on a thorough physical examination with a suspicion of abdominal injuries ${ }^{5)}$. In order to notice the site and extent of the injury and to plan an operative method, ultrasonography or enhanced computed tomography should be obtained a stable patient. In addition, hemodynamically stable patients should undergo angiography since it provides critical information for decision-making of treatment and radiological treatment can be done with transcatheter arterial embolization ${ }^{6-8)}$. In our case, angiography could not be performed due to the patient's poor general condition with hemorrhagic shock, and an emergency operation was performed in consideration of the potential visceral arterial injury. In recent years, interventional radiological procedures have established themselves as important options in the management of some abdominal vascular injuries. However, we retrospectively thought that the control of bleeding from the right gastric artery injury might be unable to successfully managed with superselective transcatheter arterial embolization in our hospital due to the technical difficulty.

Current treatment modalities for vascular injury are various. They include repair, resection and repair, autogenous or prosthetic replacement, bypass, and ligation. This patient's trauma was limited to the upper abdomen (Fig. 3a), unlike most previously reported cases of blunt abdominal trauma, which are associated with multiple injuries. In our case, ligation was chosen because of the complete transection of the right gastric artery (Fig. 3b).
In conclusion major visceral vascular injuries can result in high morbidity and mortality. A high index of suspicion is needed to provide prompt diagnosis and adequate treatment. Successful management of patients with injury to the visceral arteries must include aggressive volume replacement and rapid exposure of the injuries. In this patient with disruption of the right gastric artery, identification and exposure of this unusual injury allowed simple ligation as definitive treatment. It is of crucial importance that, regardless of shock, laparotomy is promptly performed at the appropriate time.

\section{References}

1) Nitecki S, Karmeli R, Ben-Arieh Y, et al: Seatbelt injury to the common iliac artery: report of two cases and review of the literature. J Trauma 1992; 33: 935-8.

2) Udekwu OP, Jannetta J, Udekwu AO, et al: Disruption of the gastroduodenal artery and right gastric artery following blunt trauma. Injury 1993; 24: 225-6.

3) Muck PE, Nunez TC, Hruska L, et al: Blunt injury to the external iliac artery: a case report. Am Surg 2002; 68: 11-4.

4) Reisman JD, Morgan AS: Analysis of 46 intra-abdominal aortic injuries from blunt trauma: case reports and literature review. J Trauma 1990; 30: 1294-7.

5) Lock JS, Huffman AD, Johnson RC: Blunt trauma to the abdominal aorta. J Trauma 1987; 27: 674-7.

6) McDonald EJ Jr, Goodman PC, Winestock DP: The clinical indications for arteriography in trauma to the extremity. A review of 114 cases. Radiology 1975; 116: 45-7.

7) Marty-Ane $\mathrm{CH}$, Alric $\mathrm{P}$, Prudhomme $\mathrm{M}$, et al: Intravascular stenting of traumatic abdominal aortic dissection. J Vasc Surg 1996; 23: 156-61.

8) Cooper C, Rodriguez A, Omert L: Blunt vascular trauma. Curr Probl Surg 1992; 29: 281-357. 


\section{症例報告}

\section{腹部鈍的外傷による右胃動脈単独損傷の 1 例}

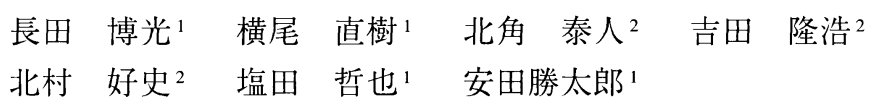

要旨 症例は 54 歳の男性。既往歴は44歳時に外傷性小腸穿孔のため手術施行。48歳時より発作性心房細動にて 内服治療中であった。2002 年 6 月午前 11 時頃, 作業場で小型重機運転中に横転し, 一時的に小型重機の下敷き となった。その際，操作レバーにて上腹部を強打し，上腹部激痛を主訴に午前 11 時 45 分当院へ救急搬送された。 来院時は意識清明，血圧 130/80 mmHg，脈拍 70/min・整であり，顔面は苦悶状でやや荅白であった。腹部は剣状 突起下でゴルフボール大の隆起を認め, 自発痛・圧痛は著明であった。腹部造影 CTで, 胃の背側に多量の液体 貯留像を認めるとともに, 胃前庭部背側で造影剤の血管外漏出像を認めた。短時間のうちにショック状態となっ たため, 来院 2 時間後に緊急開腹術を施行したところ, 上腹部の腹直筋筋膜は断裂し, 皮下に一部大網の脱出を 認めた。網囊内に大量の血腫と右胃動脈からの出血を認めたため右胃動脈を結紮止血した。術後経過としては, 再 出血などの合併症は認めず，第14病日に退院した。腹部鈍的外傷による右胃動脈単独損傷が原因の稀有な腹腔内 出血を経験したので報告する。

（日救急医会誌 $2005 ； 16 ： 182-6$ )

キーワード：腹部鈍的外傷, 右胃動脈損傷, 腹腔内出血, 出血性ショック

1 高山赤十字病院外科 2 同院救急部

著者連絡先：干 606-8507 京都市左京区聖護院河原町 54 京都大学大学院医学研究科消化器外科学講座

原稿受理日：2004 年 12 月 6 日（04-075） 